Brit. Heart f., 1967, 29, 533.

\title{
Ventricular Structure and Function After Radical Correction of the Tetralogy of Fallot
}

\author{
K. A. HALLIDIE-SMITH, M. DULAKE, M. WONG*, C. M. OAKLEY†, AND J. F. GOODWIN \\ From the Department of Medicine (Unit of Clinical Cardiology), Postgraduate Medical School of London, and Ham- \\ mersmith Hospital, London W.12
}

Total, or radical, surgical correction of the tetralogy of Fallot has now become standard practice. Mortality figures differ widely and vary from none in a series of 41 patients (Malm et al., 1963) to between 30 and 40 per cent in other hands. In 1960 Kirklin et al., reported a 17 per cent mortality in 91 patients, and in 1961 Barnard and Schrire published a similar mortality in 42 patients, though Bahnson et al. (1962) recorded a 30 per cent mortality in 147 patients. In experienced hands today the mortality should be under 20 per cent.

The main hazards of the operation relate to unusual intracardiac deformity, complete heart block, post-operative pulmonary odema and insufficiency, hæmorrhagic problems, and incomplete correction of the lesions. Although complete heart block has become much less common with increased surgical expertise, the other hazards remain, and are appreciably greater in severely cyanotic patients with high hæmatocrit values, and particularly in those with a hypoplastic right ventricular outflow tract, small pulmonary valve ring, or absent crista supraventricularis (bulboventricular defect).

The object of this paper is to present in detail the results of investigation in 24 patients following radical correction. No attempt will be made to analyse the results of operation in detail in the entire series, for these results will subsequently be published in full, but brief comments will be made in order to provide a background for the detailed studies on this smaller group.

Since the operation for radical correction is a complex one, and since it involves a large ventriculotomy, we felt it important to investigate fully the

Received September 28, 1966.

$\star$ On study leave from Cardiovascular Research Institute, San Francisco, California, U.S.A.

$\uparrow$ Supported by the British Heart Foundation. subsequent structure and function of the heart in patients who survived the operation, with special reference to long-term prognosis.

\section{Patients Studied and Technique Used}

Between 1958 and 1965, 133 patients were treated by radical correction, by Mr. W. P. Cleland and Professor H. H. Bentall, under cardiopulmonary bypass directed by Dr. Denis Melrose. Between 1962 and 1965, 32 patients were treated by closed infundibular resection, as a preliminary to radical correction at a subsequent later stage.

In view of the greater risks in patients with high hæmatocrit (over 65\%), unusual anatomy (bulboventricular defect, or double outlet right ventricle), or small body size, a policy of two-stage correction for such patients has been evolved, closed infundibular resection being followed 6 months to 2 years later by closure of the ventricular septal defect.

All patients have been investigated before operation by selective right ventricular angiocardiography and the majority by full right heart catheterization also. Special attention has been paid to the position of the aortic root and pulmonary artery, the site and size of the ventricular septal defect, the presence of the crista in lateral and frontal projections, and the size of the pulmonary valve ring. The detailed analysis and the correlation of angiographic and surgical anatomy have been reported by Smith et al. (1965).

Studies were made on 24 patients 1 month to 6 years after radical correction; 21 of these had been treated in one stage, and 3 in two stages.

The indications for investigation were varied. Four patients were studied because their post-operative condition caused anxiety and suggested pertsisence of the ventricular septal defect, severe pulmonary incompetence, or considerable residual pulmonary stenosis. The other patients, who were dramatically improved, did not give rise to anxiety, and were investigated in 533 
Right heart catheterization was performed in all 24 patients, and in 17 selective right ventricular angiocardiography was carried out. In 10 patients, all of whom had a strictly intact ventricular septum, ventricular volumes were estimated by the thermodilution technique (Rapaport et al., 1965). In 5 patients, studies were made before and after isoprenaline infusion, to assess the performance of the right ventricle under stress.

\section{RESULTS}

\section{Over-all Results of Operations}

The over-all results of surgical treatment may be divided into two phases. Phase 1 , between 1958 and 1962, was characterized by one-stage procedures only, and included early inexperience before the present skill in surgical and pre- and post-operative management had been acquired. Not surprisingly, the mortality was 38 per cent in the first 65 patients, deaths occurring most frequently in the severely cyanotic patients. In the second phase, when severely cyanosed patients and those with anatomical variants (as defined above) were rejected for one-stage correction, the mortality of one-stage correction was only 19 per cent in 56 patients.

In all, there were 36 deaths in 133 one-stage radical corrections. Of these 36,7 had open (persistent) ventricular septal defects, and death occurred in the early post-operative period; 2 late deaths occurred, one after a second operation to close the defect, and one from bacterial infection of the heart.

Of the survivors, all had improvement in effort tolerance and reduction in cyanosis, both of which were usually dramatic. Persistence of the ventricular septal defect was suspected in 25 patients, but was clinically unimportant in all except 4 patients. Some degree of pulmonary valve incompetence was suspected in about half the patients on the basis of an early diastolic murmur at the left sternal edge, but it was clinically important in only three.

Clinically satisfactory signs were the disappearance of cyanosis and dyspncea (hyperventilation); a soft short pulmonary systolic murmur, audible (though delayed) pulmonary valve closure, and a soft or absent pulmonary diastolic murmur. The jugular venous pressure was raised in at least 50 per cent of patients for up to one year after operation, and this will be discussed fully later.

Full data on causes of death, incidence of heart block, and clinical status of all surviving patients will be published elsewhere. The foregoing figures are given to set the stage for the analysis of the results of special investigation in the 24 patients described here.

The results of infundibular resection (first stage of two-stage procedure) will also be reported in full elsewhere. Of 32 patients, 3 died, 2 during subsequent second stage procedures; 8 other patients did well after the second stage and the remainder have not yet had the second stage.

\section{Results of Investigation in 24 Patients after Radical Correction}

Surgical Anatomy. Stenosis of the outflow tract of the right ventricle was present in all patients and was solely valvar in 4, solely infundibular in 9, and combined in 11 . Of the 4 patients with lone valvar stenosis, 3 had an uncommonly small valve ring; 2 had a bulboventricular defect, and one had a supracristal ventricular septal defect.

The ventricular septal defect was large and occupied the usual site extending from the crista supraventricularis to the septal cusp of the tricuspid valve in 18 patients. The size ranged from $4 \times 2$ $\mathrm{cm}$. to $1.5 \times 2 \mathrm{~cm}$. Six patients had unusual defects which were subcristal in 2 and bulboventricular (with absent or split crista) in 3, while the remaining patient had an infracristal defect with an additional left ventricular-right atrial shunt and a cleft tricuspid valve suggesting a partial form of atrio-ventricular canal (Case 5).

Clinical Status after Operation. Dyspncea was much less severe than before operation and, in all except 3 patients with open defects or severe pulmonary incompetence, disappeared entirely. Cyanosis was abolished in all patients except one in whom it appeared only on effort.

After operation, the systolic murmur due to pulmonary stenosis was grade 4 (out of 4 ) in 6 patients, grade 3 in 15 , grade 2 in 2 , and grade 1 in one patient. The last of these had virtual pulmonary atresia and was operated upon in 2 stages: after the first stage the systolic murmur increased. The murmur was accompanied by a thrill in 11 patients; it tended to diminish in intensity near the second heart sound, and never extended past aortic valve closure.

After operation the murmur was grade 4 in 4 patients, grade 3 in 13 patients, grade 2 in 6 patients, and grade 1 in one patient (Fig. 1). A thrill was present in only 4 patients, and in 2 patients the initially loud murmur became softer with the passage of several months. The systolic murmur was full length in 2 patients who had a left-to-right shunt through a persistent ventricular septal defect (Fig. 2). Of the 4 patients with a grade 4 murmur, 3 had left-to-right shunts, and 2 had residual obstruction to right ventricular outflow, $(76,68$, and $45 \mathrm{~mm}$. $\mathrm{Hg}$ gradients, respectively); 3 of these 


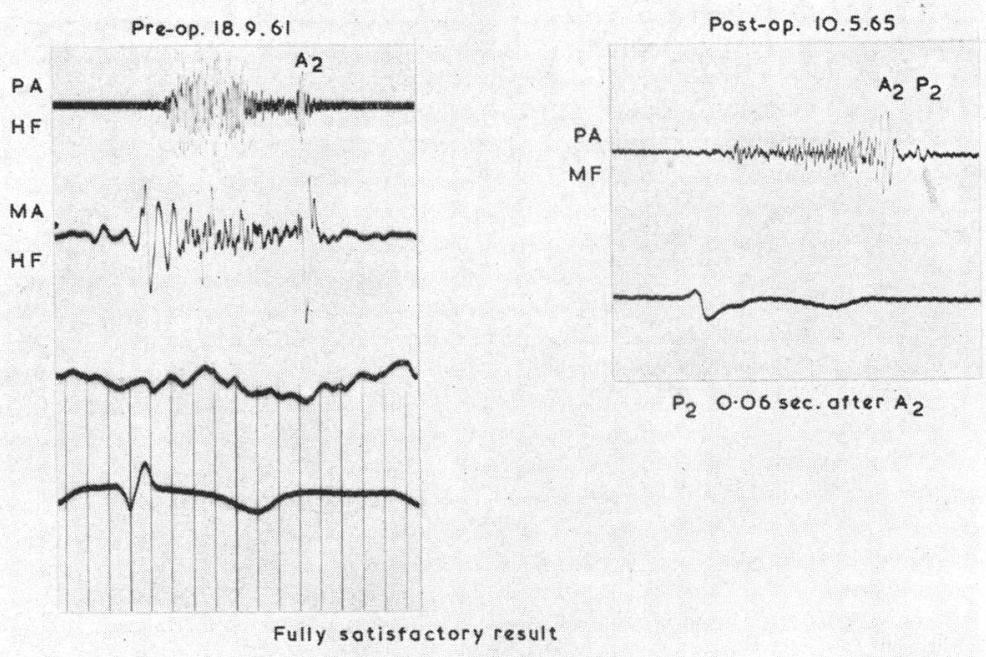

FIG. 1.-Phonocardiogram before and after radical correction in Case 2. The systolic murmur had almost disappeared and pulmonary closure was audible after operation. $P A=$ pulmonary area; $M F=$ medium frequency; $\mathbf{H F}=$ high frequency; $M A=$ mitral area; $P_{2}=$ pulmonary valve closure; $A_{2}=$ aortic valve closure.

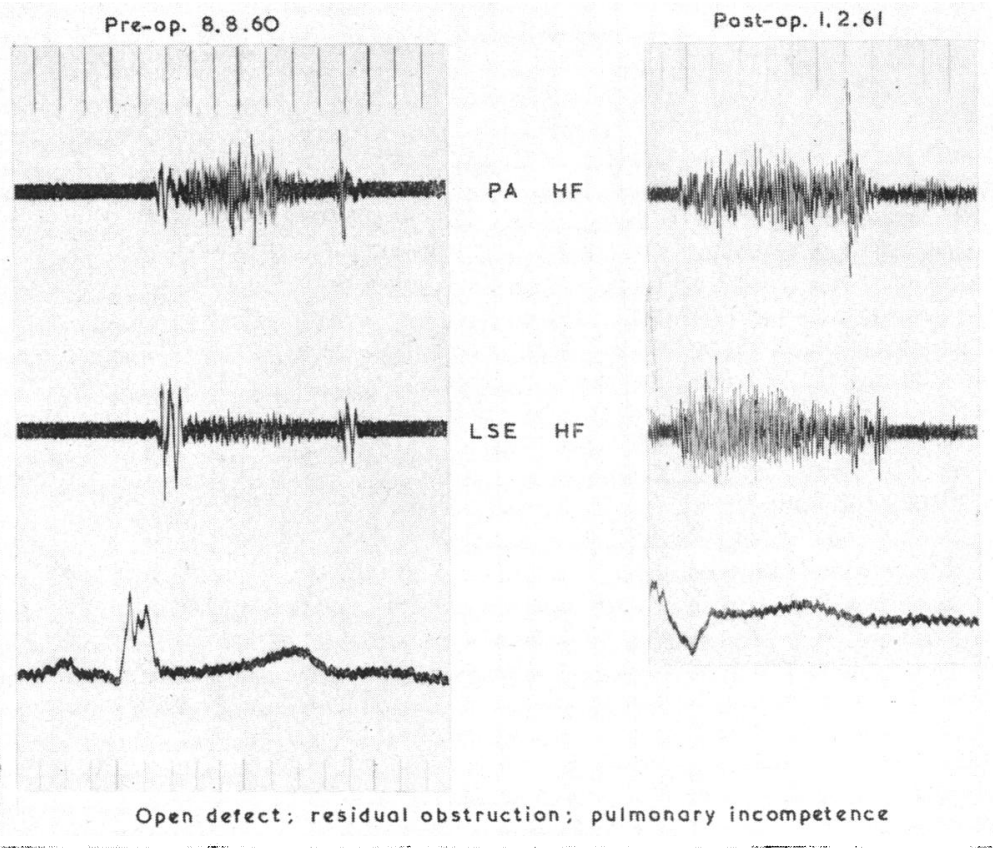

Fig. 2.-Phonocardiogram of Case 12 with open defect, residual obstruction, and pulmonary incompetence. After operation the pansystolic murmur due to the left-to-right shunt at ventricular level and the faint early diastolic murmur were recorded. Pulmonary closure was not seen. PA=pulmonary artery; LSE =left sternal edge; $\mathbf{H F}=$ high frequency. 
TABLE I

POST-OPERATIVE JUGULAR VENOUS PRESSURE

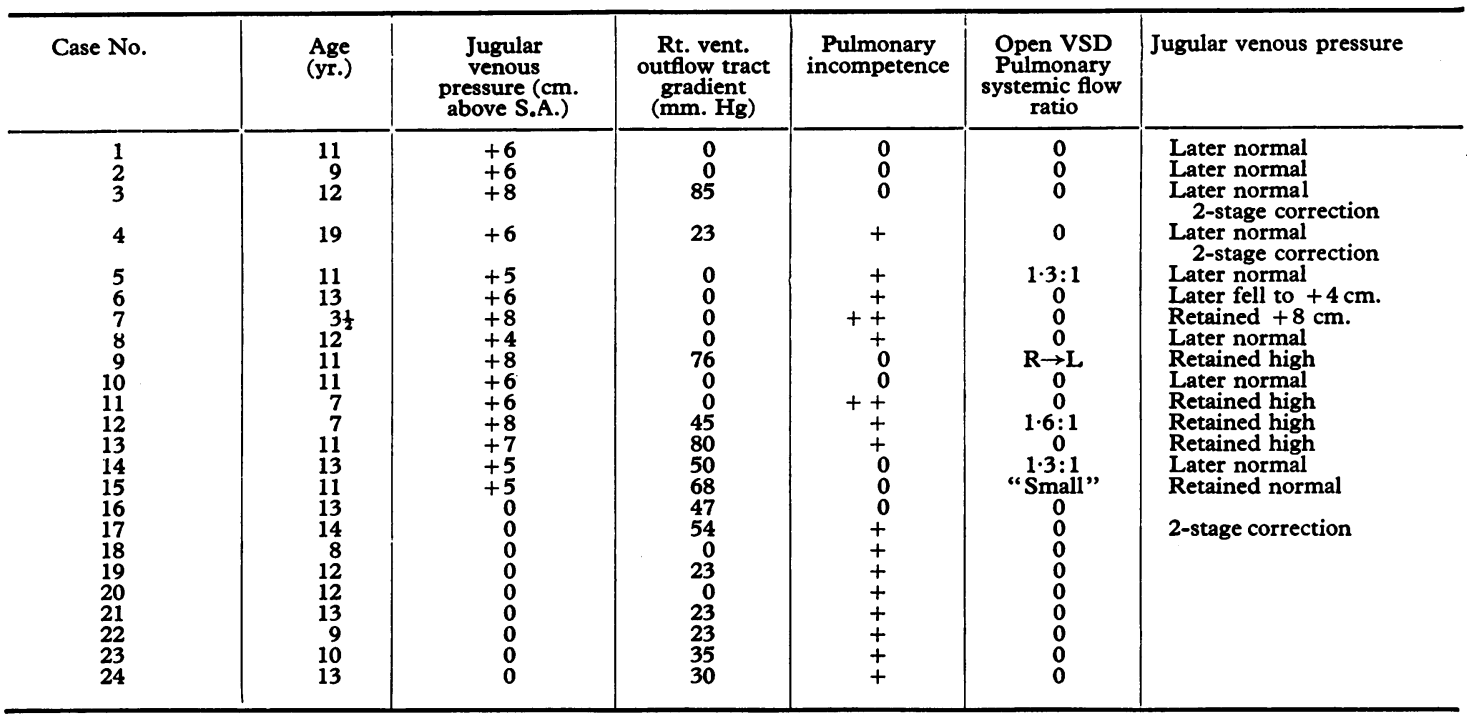

patients had pulmonary incompetence which would be expected to increase the stroke output of the ventricle and thus enhance the systolic murmur. Of the 13 patients with a grade 3 murmur, 6 had pulmonary incompetence which was severe in one, one had a left-to-right shunt, and one a right-toleft shunt. A gradient over $20 \mathrm{~mm}$. $\mathrm{Hg}$ across the right ventricular outflow tract was present in 7 of the 13 patients, but was appreciable in only $4(47,50$, 76, $80 \mathrm{~mm}$. $\mathrm{Hg}$ gradients, respectively). The gradient of $76 \mathrm{~mm}$. $\mathrm{Hg}$ was associated with a rightto-left shunt. Two patients had neither pulmonary incompetence, a gradient, nor a shunt. Thus a loud residual systolic murmur usually indicated some degree of residual obstruction, and was exaggerated by pulmonary incompetence and a persistent shunt, but was compatible with a fully satisfactory result. The significance of the murmur could not be reliably assessed in the presence of pulmonary incompetence. A loud murmur immediately after operation was compatible with residual obstruction which might resolve, as suggested in the two patients without a shunt or pulmonary incompetence in whom subsequent catheterization revealed no gradient.

An early diastolic murmur of pulmonary incompetence was present in 15 patients and was grade 2 or less in 14 (Fig. 2). A mid-diastolic murmur at the apex was present in only one patient who had a left-to-right shunt at ventricular level. Pulmonary valve closure was audible in 17 patients, and was delayed in all.

The jugular venous pressure was raised more than $+3 \mathrm{~cm}$. above the sternal angle in 15 patients after the operation, and ranged from +8 to $+4 \mathrm{~cm}$. It fell to normal within 6-9 months in all but 3 patients who had persistent shunts or severe pulmonary incompetence. Table I relates the jugular venous pressure to the residual gradient, to pulmonary incompetence, and to a persistent ventricular septal defect. The relation of the venous pressure to right atrial and right ventricular pressures will be described later.

It will be seen that a persistent gradient and pulmonary incompetence were associated with both a raised and a normal venous pressure, though there was a slight tendency for the venous pressure to be raised more frequently in association with rather higher gradients, but the differences are not significant. It is noteworthy, however, that, of the 6 patients who retained a high jugular venous pressure one year after operation, 4 had an open defect and one had severe pulmonary incompetence. Cases 9 and 14 (both with considerable residual obstruction) were investigated within 2 months of operation and no comment can be made on the persistence of their raised pressures, but it seems possible that in Case 14 with no shunt the raised pressure may return to normal.

A raised jugular venous pressure therefore may 


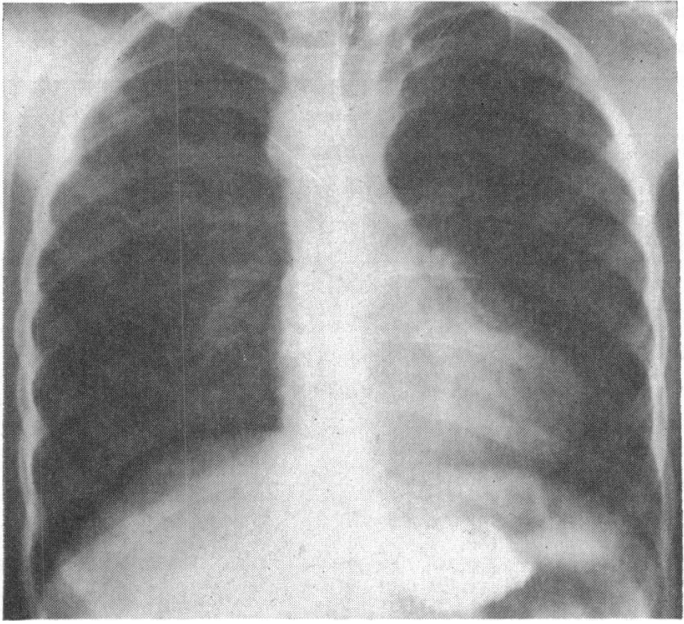

(a)

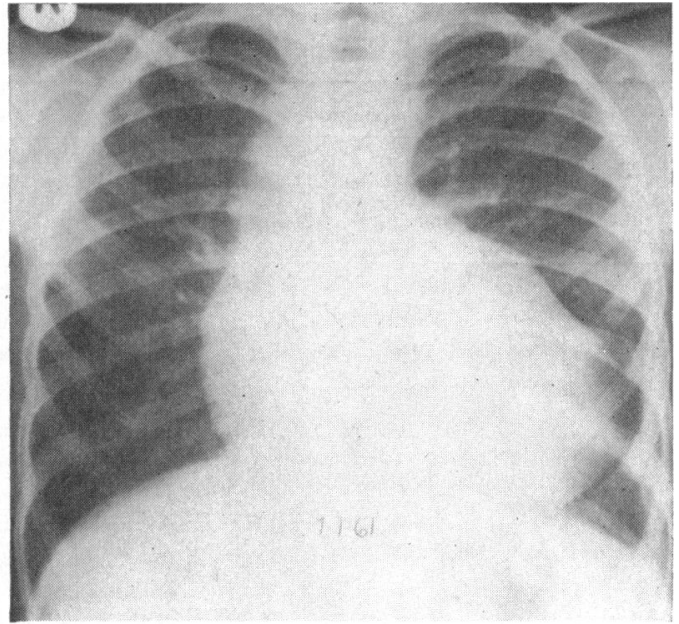

(b)

FIG. 3.-Six-foot postero-anterior radiographs of the chest of Case 11 before (a) and after (b) operation showing considerable enlargement due to pulmonary incompetence.

be expected in more than 50 per cent of cases after operation, and is likely to fall to normal within one year unless there is a persistent shunt or severe pulmonary incompetence. The presence of a raised pressure after one year points to one or other of these complications, perhaps with added appreciable residual obstruction. The cause of the raised pressure in satisfactory patients is uncertain and will be discussed further in the section on hæmodynamic data. However, the fact that in many patients the investigations were performed after the venous pressure had become normal makes correlation between right ventricular and venous pressures difficult in the immediate post-operative period.

We believe that a raised venous pressure should not be regarded as a sign of congestive heart failure (Bristow et al., 1961) unless other signs (especially an enlarged liver) are present also, and this view is borne out by the finding of hepatomegaly only in those patients with left-to-right shunts or severe pulmonary incompetence.

Hamatocrit and Hamoglobin Values. Before operation the hæmatocrit ranged from 84 to 40 per cent and the hæmoglobin from 24 to 13.6 g./100 ml. After operation both hæmatocrit and hæmoglobin were normal or subnormal, the highest hæmatocrit being 46 per cent and the highest hæmoglobin being $15 \mathrm{~g} . / 100 \mathrm{ml}$. Subnormal values could be attributed to post-operative anæmia in the early post-operative phase.

Electrocardiogram. Before operation 23 patients had right ventricular hypertrophy, and one had right bundle-branch block. Right ventricular hypertrophy was grade 2 in 7, grade 3 in 12, and grade 4 in 4 patients (Goodwin and Abdin, 1959). Right atrial enlargement shown by pointed $P$ waves $2.5 \mathrm{~mm}$. or more in amplitude was present in 9 patients. All had right axis deviation which was between $+90^{\circ}$ and $+150^{\circ}$ in 22 , and exceeded $+150^{\circ}$ in 2 patients.

After operation 22 patients showed complete, and one patient incomplete, right bundle-branch block.

The cardiac axis was between $+30^{\circ}$ and $+150^{\circ}$ in 22 patients, and left axis deviation $\left(-110^{\circ}\right.$ and $-20^{\circ}$ ) was present in 2 . One of these (Case 5, axis $-110^{\circ}$ ) had an atrio-ventricular canal type of defect.

One patient (Case 14) had left ventricular hypertrophy, because of an open supracristal defect.

No patient had complete heart block.

Plain Chest Radiograph. Slight cardiac enlargement was usual, but considerable enlargement occurred when severe pulmonary incompetence resulted, or when there was a left-to-right shunt. Thus in Case 11 the cardiothoracic ratio increased from 49 to 67 per cent (Fig. 3).

Hamodynamics (Table II). Pre-operative hæmodynamic data were available in 18 patients, but were not always complete for technical or other reasons. Post-operative data were complete on all 24 cases except for Case 24 where right atrial pressure was not measured.

Before operation the hæmodynamics were typical of tetralogy. Systolic right ventricular pressure was at systemic level, varying between 100 and 
TABLE II

HAMODYNAMICS

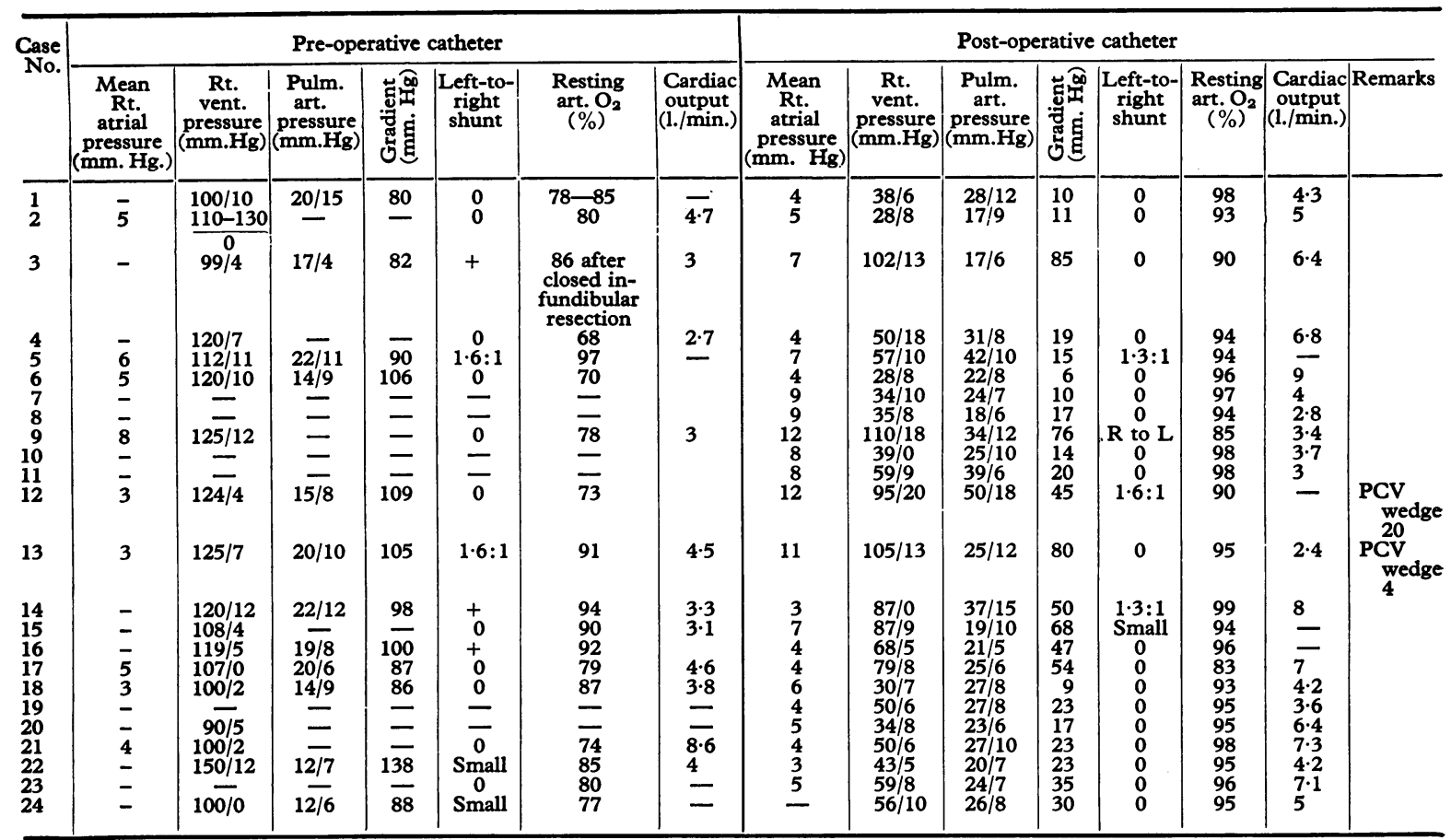

$150 \mathrm{~mm} . \mathrm{Hg}$, and the pulmonary artery pressure from $12 / 6$ to $22 / 11 \mathrm{~mm}$. Hg. Six patients had a small left-to-right shunt at ventricular level, the ratio of pulmonary to systemic flow not exceeding $1 \cdot 6: 1$. The arterial oxygen saturation ranged from 70 to 95 per cent at rest, and always fell after effort by at least 10 per cent and sometimes by as much as 25 per cent.

A systolic gradient between the right ventricle and pulmonary artery was present in all patients after operation, but was $20-25 \mathrm{~mm}$. $\mathrm{Hg}$ or less in 10 (Fig. 4) and between 25 and $50 \mathrm{~mm}$. $\mathrm{Hg}$ in 7 .
Gradients in excess of $50 \mathrm{~mm} . \mathrm{Hg}$ were present in the remaining 5 patients: 4 had pulmonary incompetence, and 2 had persistence of the ventricular septal defect (Fig. 5 and 6).

Table III shows the association of residual lesions. It will be seen that 5 patients had a residual ventricular septal defect, and that this was always associated with either pulmonary incompetence or outflow tract obstruction.

Applying the very rigorous requirement of minimal outflow tract obstruction (less than $25 \mathrm{~mm}$. $\mathrm{Hg}$ ) without any pulmonary incompetence, only 4

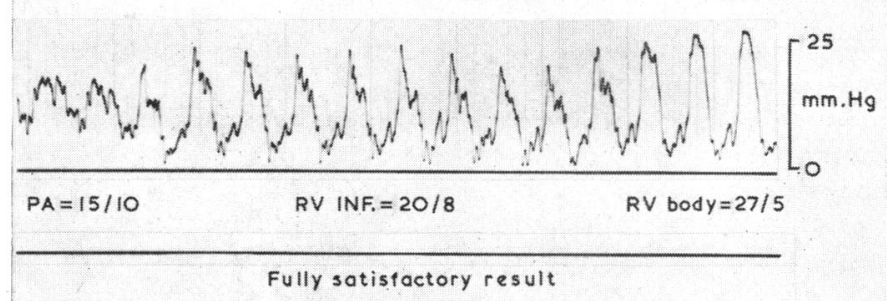

Fig. 4.-Withdrawal tracing from pulmonary artery to right ventricle in Case 2 , showing normal right ventricular pressures and relief of outflow obstruction. $P A=$ pulmonary artery; $R V=$ right ventricle; INF $=$ infundibulum. 


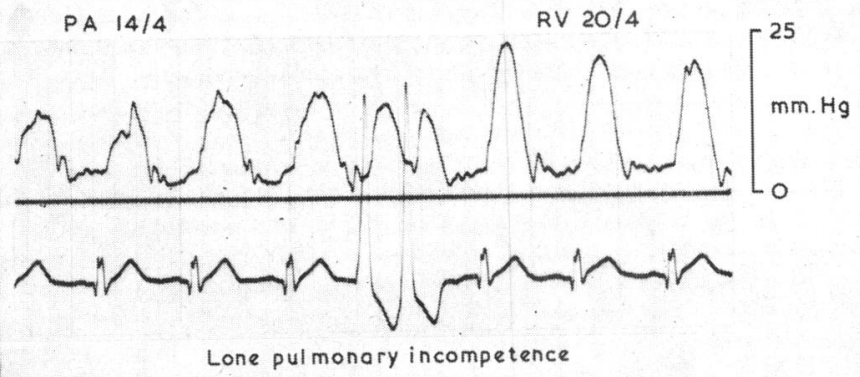

FIG. 5.-Withdrawal tracing from pulmonary artery (PA) to right ventricle (RV) in Case 7 with lone pulmonary incompetence, showing low pulmonary diastolic pressure equal to that of the right ventricle.

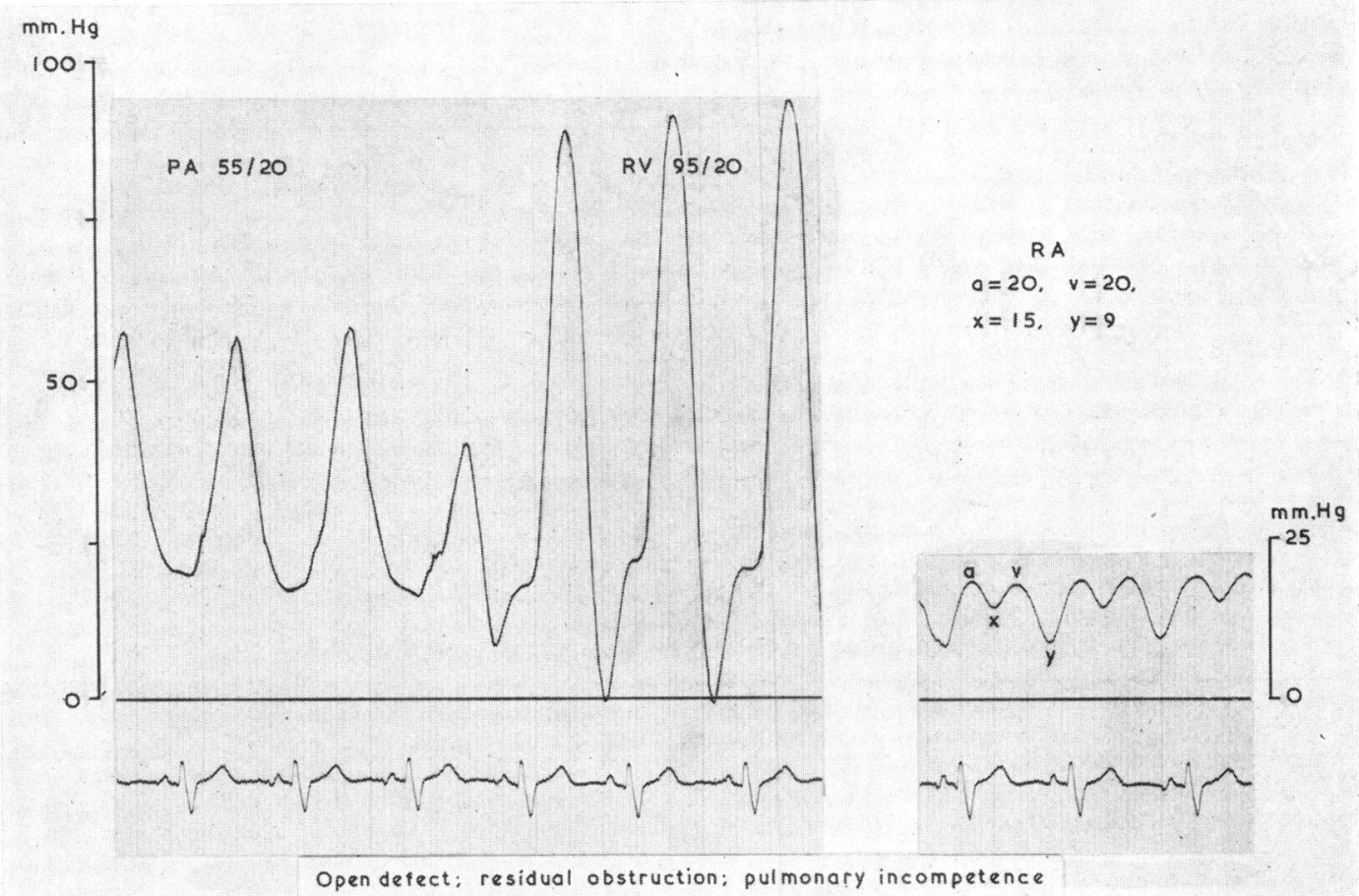

FIG. 6.-Pressure pulses in pulmonary artery (PA), right ventricle (RV), and right atrium (RA) in Case 12, showing high right ventricular diastolic pressure, equal to pulmonary artery diastolic pressure, high right ventricular systolic pressure, and raised right atrial pressure, with poor " $x$ " descent suggesting tricuspid incompetence. Note pulmonary hypertension.

TABLE III

RESIDUAL LESIONS AFTER OPERATION

\begin{tabular}{l|c}
\hline & Patients \\
\hline Lone residual obstruction (gradient greater than & \\
25 mm. Hg) & 2 \\
Lone pulmonary infundibular incompetence (defined & 9 \\
clinically) & 4 \\
Pulmonary incompetence plus residual obstruction & 1 \\
Open defect plus pulmonary incompetence & 3 \\
Open defect plus residual obstruction & 1 \\
Open defect plus pulmonary incompetence plus & \\
\hline
\end{tabular}


patients can be regarded as 'fully satisfactory' (Fig. 4). However, in only 2 patients was pulmonary incompetence of appreciable severity, while only 5 patients had gradients of over $50 \mathrm{~mm}$. $\mathrm{Hg}$, and these may be expected to resolve with time, so that a highly satisfactory result was achieved in most. Anxiety must be felt, however, for the 5 patients with residual defects, even though symptomatically they have been greatly improved. In the other 19 patients, results have been excellent from the hæmodynamic aspect.

\section{Relation of Results of Operation to Anatomy Found at Operation and Operative Procedure}

Tables IV and V relate the results to the surgical anatomy, and to the presence or absence of outflow tract or septal patches applied by the surgeons, respectively. No clear correlation emerges, but it is perhaps significant that 3 of the 5 patients with persistent shunts had complex or multiple ventricular septal defects, while only 1 of the 4 fully satisfactory patients had such defects. Of the 4 fully successful patients, 3 had lone infundibular stenosis, which was present in only 1 of the 5 patients with persistent shunts. The numbers are naturally too small for any definite conclusions to be drawn, but it seems reasonable to suppose that the more complex anatomies such as combined valvar and infundibular stenosis, and unduly complicated forms of ventricular septal defects, are more likely to be associated with residual defects after operation. Lone valvar stenosis, a small valve ring, and an atypical ventricular septal defect were compatible with a fully satisfactory result, though combined valvar and infundibular stenosis militated against complete relief of obstruction and prevented complete competence of the pulmonary valve. The combined stenosis, however, did not prevent complete closure of the ventricular septal defect, which was achieved in 9 out of the 11 patients with combined stenosis.

Table V shows that only 7 of the 24 patients were treated by direct suture of the ventricular septal defect, without any form of patch of prosthesis, though 4 patients had direct suture over teflon pledgets. In those requiring a patch repair of the ventricular septal defect, or an outflow prosthesis to relieve severe narrowing, residual abnormalities seemed more common. In this small group it would be unwise to draw firm conclusions, but this trend is suggested by our results, for 6 of the 9 with lone pulmonary incompetence, all patients with incompetence and residual obstruction, and 3 of the 5 patients with open defects, all had a prosthesis to the ventricular septal defect or outflow tract, which appears to favour residual obstruction. Again, numbers are too small to permit accurate conclusions.

TABLE IV

RELATION OF SURGICAL ANATOMY TO RESULTS

\begin{tabular}{|c|c|c|c|c|c|c|}
\hline Anatomy & $\begin{array}{l}\text { Fully } \\
\text { satisfactory }\end{array}$ & $\begin{array}{l}\text { Lone residual } \\
\text { obstruction }\end{array}$ & $\begin{array}{l}\text { Lone pulmonary } \\
\text { incompetence }\end{array}$ & $\begin{array}{l}\text { Pulmonary incompe- } \\
\text { tence plus obstruction }\end{array}$ & Open defect & Total \\
\hline $\begin{array}{l}\text { Combined infundibular and } \\
\text { valvar stenosis } \\
\text { Lone valvar stenosis } \\
\text { Small valve ring } \\
\text { Lone infundibular stenosis } \\
\text { Atypical ventricular septal defect } \\
\text { Supracristal 2 } \\
\text { Bulboventricular } 3 \\
\text { Multiple 1 }\end{array}$ & $\begin{array}{l}0 \\
1 \\
1 \\
3 \\
1\end{array}$ & $\begin{array}{l}1 \\
1 \\
1 \\
0 \\
1\end{array}$ & $\begin{array}{l}6 \\
0 \\
1 \\
3 \\
1\end{array}$ & $\begin{array}{l}2 \\
1^{\star} \\
0 \\
2 \\
0\end{array}$ & $\begin{array}{l}2 \\
2 \\
1+ \\
1 \\
3\end{array}$ & $\begin{array}{r}11 \\
4 \\
4 \\
9 \\
6\end{array}$ \\
\hline
\end{tabular}

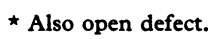

t Also pulmonary incompetence and obstruction.

TABLE V

RELATION OF SURGICAL PROSTHESIS TO RESULT

\begin{tabular}{|c|c|c|c|c|c|c|}
\hline Procedure & $\begin{array}{c}\text { Fully } \\
\text { satisfactory }\end{array}$ & $\begin{array}{l}\text { Lone residual } \\
\text { obstruction }\end{array}$ & $\begin{array}{l}\text { Lone pulmonary } \\
\text { incompetence }\end{array}$ & $\begin{array}{l}\text { Pulmonary incompetence } \\
\text { and obstruction }\end{array}$ & Open defect & Total \\
\hline $\begin{array}{l}\text { Direct suture of ventricular } \\
\text { septal defect } \\
\text { Patch for ventricular septal } \\
\text { defect and/or for outflow tract }\end{array}$ & $\begin{array}{l}2 \\
2\end{array}$ & $\begin{array}{l}0 \\
2\end{array}$ & $\begin{array}{l}3 \\
6\end{array}$ & $\begin{array}{l}0 \\
4\end{array}$ & $\begin{array}{l}2 \\
3\end{array}$ & $\begin{array}{r}7 \\
17\end{array}$ \\
\hline Total & 4 & 2 & 9 & 4 & 5 & 24 \\
\hline
\end{tabular}


TABLE VI

RIGHT ATRIAL MEAN, RIGHT VENTRICULAR, AND PULMONARY ARTERY DIASTOLIC PRESSURES, BEFORE AND AFTER OPERATION

\begin{tabular}{|c|c|c|c|c|c|c|c|c|c|}
\hline \multirow[t]{2}{*}{$\begin{array}{l}\text { Case } \\
\text { No. }\end{array}$} & \multicolumn{2}{|c|}{$\begin{array}{l}\text { Mean right } \\
\text { atrial pressure } \\
(\mathrm{mm} . \mathrm{Hg})\end{array}$} & \multicolumn{2}{|c|}{$\begin{array}{c}\text { Right } \\
\text { ventricular } \\
\text { diast. pressure }\end{array}$} & \multicolumn{2}{|c|}{$\begin{array}{l}\text { Pulmonary } \\
\text { artery diast. } \\
\text { pressure }\end{array}$} & \multirow[t]{2}{*}{$\begin{array}{l}\text { Pulmonary } \\
\text { incompetence } \\
\text { after }\end{array}$} & \multirow{2}{*}{$\begin{array}{c}\text { Post-operative clinical } \\
\text { jugular venous } \\
\text { pressure }>+3 \mathrm{~cm} . \\
\text { above sternal angle }\end{array}$} & \multirow[t]{2}{*}{ Remarks } \\
\hline & Before & After & Before & After & Befor & After & & & \\
\hline $\begin{array}{r}1 \\
2 \\
3 \\
4 \\
5 \\
6 \\
7 \\
8 \\
9 \\
10 \\
11 \\
12 \\
13 \\
14 \\
15\end{array}$ & $\begin{array}{l}\overline{5} \\
\overline{-} \\
\overline{6} \\
5 \\
\overline{-} \\
\overline{8} \\
\overline{3} \\
3 \\
3 \\
\overline{3}\end{array}$ & $\begin{array}{r}4 \\
5 \\
7 \\
4 \\
7 \\
4 \\
9 \\
9 \\
12 \\
8 \\
12 \\
12 \\
11 \\
3 \\
7\end{array}$ & $\begin{array}{r}10 \\
0 \\
4 \\
7 \\
11 \\
10 \\
- \\
\overline{12} \\
- \\
\overline{4} \\
7 \\
12 \\
4\end{array}$ & $\begin{array}{r}6 \\
8 \\
13 \\
18 \\
10 \\
8 \\
10 \\
8 \\
18 \\
0 \\
9 \\
20 \\
13 \\
0 \\
9\end{array}$ & $\begin{array}{r}15 \\
\overline{4} \\
\overline{11} \\
9 \\
\overline{-} \\
\overline{-} \\
\overline{-} \\
8 \\
10 \\
12 \\
-\end{array}$ & $\begin{array}{r}12 \\
9 \\
6 \\
8 \\
10 \\
8 \\
7 \\
6 \\
10 \\
10 \\
6 \\
18 \\
12 \\
15 \\
10\end{array}$ & $\begin{array}{l}0 \\
0 \\
0 \\
+ \\
+ \\
+ \\
++ \\
+ \\
0 \\
0 \\
++ \\
+ \\
+ \\
0 \\
0\end{array}$ & $\begin{array}{l}+ \\
+ \\
+ \\
+ \\
+ \\
+ \\
+ \\
+ \\
+ \\
+ \\
+ \\
+ \\
+ \\
+ \\
+\end{array}$ & $\begin{array}{l}\text { Fully satisfactory } \\
\text { Fully satisfactory } \\
\text { Pulmonary atresia } \\
\text { Persistent VSD; left-to-right shunt } \\
\text { Persistent VSD; right-to-left shunt; } \\
\text { Fully satisfactory } \\
\text { Persistent VSD; left-to-right shunt } \\
\text { Persistent VSD; left-to-right shunt } \\
\text { Persistent VSD; small left-to-right }\end{array}$ \\
\hline $\begin{array}{l}16 \\
17 \\
18 \\
19 \\
20 \\
21 \\
22 \\
23 \\
24\end{array}$ & $\begin{array}{l}\overline{5} \\
3 \\
- \\
\overline{4} \\
- \\
- \\
-\end{array}$ & $\begin{array}{l}4 \\
4 \\
6 \\
4 \\
5 \\
4 \\
3 \\
5 \\
-\end{array}$ & $\begin{array}{r}5 \\
0 \\
2 \\
\overline{0} \\
2 \\
12 \\
\overline{0}\end{array}$ & $\begin{array}{l}5 \\
8 \\
7 \\
6 \\
8 \\
6 \\
5 \\
8 \\
0\end{array}$ & $\begin{array}{l}8 \\
6 \\
9 \\
- \\
\overline{-} \\
\overline{7} \\
\overline{6}\end{array}$ & $\begin{array}{r}5 \\
6 \\
8 \\
8 \\
6 \\
10 \\
7 \\
7 \\
8\end{array}$ & $\begin{array}{c}0 \\
+ \\
+ \\
0 \\
+ \\
+ \\
+ \\
+ \\
+\end{array}$ & $\begin{array}{l}\mathbf{0} \\
0 \\
0 \\
0 \\
0 \\
0 \\
0 \\
0 \\
0\end{array}$ & Fully satisfactory \\
\hline
\end{tabular}

Right Ventricular End-diastolic Pressure, Mean Right Atrial Pressure, and fugular Venous Pressure and Pulmonary Incompetence, after Operation. Table VI shows right ventricular and pulmonary artery diastolic pressures and mean right atrial pressures before and after operation, in relation to the jugular venous pressure and the presence of pulmonary incompetence after operation.

Before operation the mean right atrial pressure was more than $5 \mathrm{~mm}$. $\mathrm{Hg}$ in only 2 of 10 patients in whom it was measured. After operation it was raised in 11 of 23 patients. In the 5 patients with persistence of the ventricular septal defect it was $7,3,12,12,7 \mathrm{~mm}$. $\mathrm{Hg}$, respectively. A level as high as $12 \mathrm{~mm}$. $\mathrm{Hg}$ was not encountered in any other patients.

The mean right atrial pressure after operation was above $5 \mathrm{~mm}$. $\mathrm{Hg}$ in 10 of 15 patients with a raised jugular venous pressure, with a range of $3-12 \mathrm{~mm} . \mathrm{Hg}$, the average being $7 \cdot 3 \mathrm{~mm}$. $\mathrm{Hg}$. The mean right atrial pressure was above $5 \mathrm{~mm}$. $\mathrm{Hg}$ in 6 of 9 patients with a normal post-operative jugular venous pressure, the range being 3-6 and the average $4 \mathrm{~mm}$. $\mathrm{Hg}$.

The right ventricular end-diastolic pressure before operation ranged from $0-12 \mathrm{~mm}$. $\mathrm{Hg}$, and was above 5 (maximum normal) in 8 patients. Of the 15 patients with a raised jugular venous pressure after operation, the end-diastolic pressure was below $5 \mathrm{~mm}$. in only 2 patients, the average being
$10 \mathrm{~mm} . \mathrm{Hg}$ and the range $0-20 \mathrm{~mm} . \mathrm{Hg}$. Of the 9 patients without post-operative increases in jugular venous pressure, the right ventricular enddiastolic pressure was above $5 \mathrm{~mm}$. $\mathrm{Hg}$ in 5 . The average was 6 and the range $0-8 \mathrm{~mm} . \mathrm{Hg}$.

Though the catheterization data were often obtained at a time when the jugular venous pressure had fallen to normal, there appeared to be a tendency for a clinically raised jugular venous pressure to be associated with raised right atrial mean and right ventricular end-diastolic pressures at catheterization.

The right ventricular end-diastolic pressure in patients with and without post-operative pulmonary incompetence ranged from $0-18 \mathrm{~mm} . \mathrm{Hg}$, with a mean of $9 \mathrm{~mm}$. $\mathrm{Hg}$.

The pulmonary artery diastolic pressure ranged from 5 to $18 \mathrm{~mm}$. $\mathrm{Hg}$ after operation, with a mean of $8 \mathrm{~mm}$. $\mathrm{Hg}$. In patients with pulmonary incompetence it ranged from 6 to 10, with a mean of $8.4 \mathrm{~mm}$. Hg. In those without pulmonary incompetence it ranged from 6 to 15, with a mean of 9.4 $\mathrm{mm}$. $\mathrm{Hg}$.

The pulmonary artery pulse pressure after operation ranged from 14 to $33 \mathrm{~mm}$. $\mathrm{Hg}$, with a mean of $19.6 \mathrm{~mm} . \mathrm{Hg}$ in patients with post-operative pulmonary incompetence, and from 8 to $24 \mathrm{~mm}$. $\mathrm{Hg}$ in those without, with a mean of $15.5 \mathrm{~mm}$. $\mathrm{Hg}$.

Thus while the diastolic right ventricular-pulmonary artery gradient did not show any trend, 

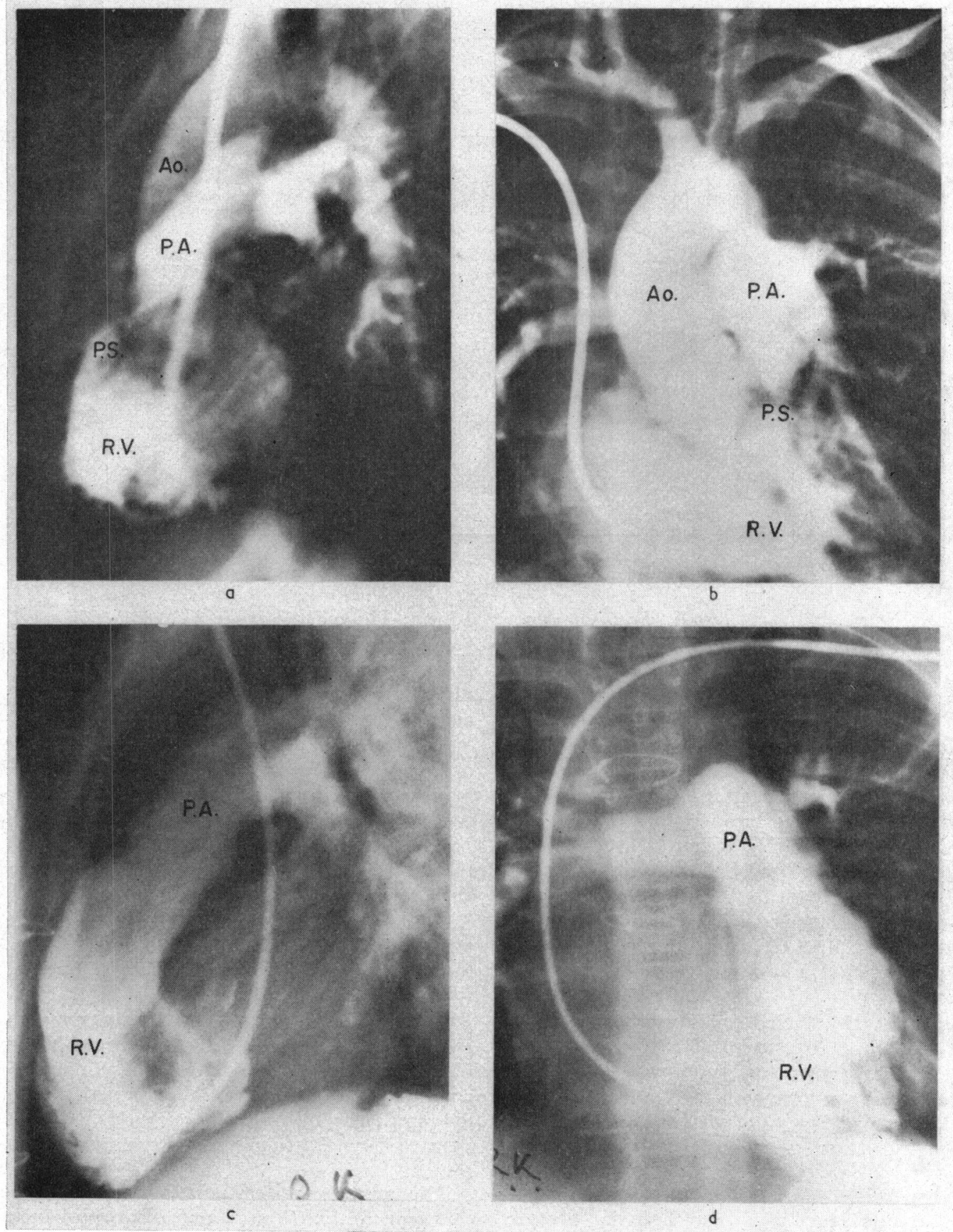

FIG. 7.-Right ventricular angiocardiogram of Case 2 before (upper) ( $a=$ lateral, $b=$ frontal) and after (lower) ( $c=$ lateral, $d=$ frontal) operation, showing excellent relief of right ventricular outflow tract obstruction and no filling of the aorta from the right ventricle following operation. R.V.= right ventricle; P.A. = pulmonary artery; Ao. = aorta; P.S. = pulmonary stenosis. 
there was a tendency towards a higher post-operative pulmonary artery pulse pressure when pulmonary incompetence was diagnosed.

Pulmonary hypertension, defined as a pressure exceeding $30 / 15 \mathrm{~mm}$. $\mathrm{Hg}$, was present in 5 cases (Cases 5, 9, 11, 12, and 14), the pressures being $42 / 10,34 / 12,39 / 6,50 / 18$, and $37 / 15 \mathrm{~mm}$. $\mathrm{Hg}$, respectively. Diastolic hypertension did not occur. Four of them had a residual shunt, and the fifth (Case 11), had severe pulmonary incompetence (Table II).

Thermodilution Studies. These were carried out in 7 patients, 4 of whom had pulmonary incompetence, 6 had a raised jugular venous pressure, and only one had residual obstruction.

End-diastolic volume and the ratio of forward stroke volume to end-diastolic volume were within the normal range at rest in all. Measurements were made after infusion of isoprenaline in 4, and all save one were normal. This patient (Case 6) had a normal ratio, but slightly increased end-diastolic volume (141 ml. $/ \mathrm{m}^{2}{ }^{2}$ - normal $\left.103 \pm 34.4 \mathrm{ml} . / \mathrm{m}^{2}\right)$. The validity of the method and the significance of these studies require confirmation and further assessment. These results have been reported in full elsewhere (Wong and Dulake, 1966).

Angiocardiography. Selective right ventricular angiocardiograms were analysed in 17 patients. In 3 of the 5 patients who had a shunt at ventricular level demonstrated by cardiac catheterization, the angiocardiogram revealed it. Residual obstruction was obvious in only 4 patients. Thirteen showed an excellent wide outflow tract (Fig. 7), but in 4 a pouch or diverticulum in the outflow tract near the ventriculotomy could be seen, similar to that described by Anderson, Newman, and Urquhart (1965) (Fig. 8). Case 7 showed massive dilatation of the right ventricle (Fig. 9), presumably due to severe pulmonary incompetence. Case 9 showed residual pulmonary stenosis and right-toleft shunt (Fig. 10).

\section{Discussion}

The results of radical correction of Fallot's tetralogy show that despite the extent of the operation the integrity of the right ventricle and its outflow tract is usually preserved. The operation is a complex and difficult one and it is gratifying to note that of the 24 patients only 5 had residual ventricular septal defects. All but one had left-to-right shunts with pulmonary to systemic flow ratios of 1.3:1 to 1.6:1 and only one had a right-to-left shunt. All save one had balanced right ventricular and arterial pressures. Only five patients had serious outflow tract gradients over $50 \mathrm{~mm}$. $\mathrm{Hg}$, and these may resolve with time. Pulmonary incompetence was severe in only 2 patients. Thus 10 patients must be considered less than satisfactory on account of considerable gradients, severe pulmonary incompetence, or a persistent septal defect. Table VII analyses the surgical anatomy and procedure in the 10 patients, and it will be seen that no single factor emerges to explain these less satisfactory results. 'Local anatomical problems, which cannot be exactly delineated, probably account for the difficulty in obtaining more satisfactory results. Four patients, by contrast, had remarkably full restoration of

TABLE VII

DATA IN 10 PATIENTS IN WHOM OPERATION RESULTS WERE LESS THAN SATISFACTORY

\begin{tabular}{|c|c|c|c|c|c|c|c|c|c|}
\hline $\begin{array}{l}\text { Case } \\
\text { No. }\end{array}$ & $\begin{array}{l}\text { Open } \\
\text { defect }\end{array}$ & $\begin{array}{c}\text { Severe residual } \\
\text { obstruction } \\
\text { (gradient } \\
\text { mm. Hg) }\end{array}$ & $\begin{array}{c}\text { Pulmonary } \\
\text { incom- } \\
\text { petence }\end{array}$ & $\begin{array}{l}\text { Right ventricular } \\
\text { end-diastolic } \\
\text { pressure (mm. Hg) }\end{array}$ & $\begin{array}{l}\text { Type of } \\
\text { ventricular } \\
\text { defect }\end{array}$ & $\begin{array}{l}\text { Type of } \\
\text { pulmonary } \\
\text { stenosis }\end{array}$ & $\begin{array}{l}\text { Small } \\
\text { valve } \\
\text { ring }\end{array}$ & Patch & $\begin{array}{l}\text { Direct suture } \\
\text { of VSD }\end{array}$ \\
\hline 3 & 0 & 85 & 0 & 13 & Infracristal & Infund. and & 0 & + & 0 \\
\hline 5 & $\stackrel{+}{\mathrm{L} \rightarrow \mathrm{R}}$ & 0 & + & 10 & $\begin{array}{l}\text { Infracristal } \\
\text { and LV-RA } \\
\text { shunt defect }\end{array}$ & $\begin{array}{l}\text { valvar } \\
\text { Infund. only }\end{array}$ & 0 & + & $\begin{array}{l}\text { Direct suture } \\
\text { over teflon } \\
\text { pledgets }\end{array}$ \\
\hline 7 & 0 & 0 & ++ & 10 & Infracristal & $\begin{array}{l}\text { Infund. and } \\
\text { valvar }\end{array}$ & $\mathbf{0}$ & 0 & $\underset{+}{\text { pieagets }}$ \\
\hline 9 & $\stackrel{+}{\mathbf{R}} \rightarrow \mathbf{L}$ & 76 & 0 & 18 & Infracristal & $\begin{array}{l}\text { Infund. and } \\
\text { valvar }\end{array}$ & 0 & + & 0 \\
\hline 11 & 0 & 0 & ++ & 9 & Infracristal & $\begin{array}{l}\text { Infund. and } \\
\text { valvar }\end{array}$ & 0 & + & 0 \\
\hline 12 & $\stackrel{+}{\rightarrow} \mathbf{R}$ & & + & 20 & Infracristal & Valvar only & + & 0 & + \\
\hline 13 & 0 & 80 & + & 13 & Infracristal & $\begin{array}{l}\text { Infund. and } \\
\text { valvar }\end{array}$ & 0 & + & 0 \\
\hline 14 & $\stackrel{+}{\rightarrow} \mathbf{R}$ & & 0 & 0 & Supracristal & Valvar only & 0 & 0 & + \\
\hline 15 & $\stackrel{+}{\rightarrow} \mathbf{R}$ & 68 & 0 & 9 & Bulboventricular & $\begin{array}{l}\text { Infund. and } \\
\text { valvar }\end{array}$ & 0 & 0 & + \\
\hline 17 & 0 & 54 & + & 8 & Infracristal & Infund. only & 0 & + & 0 \\
\hline
\end{tabular}




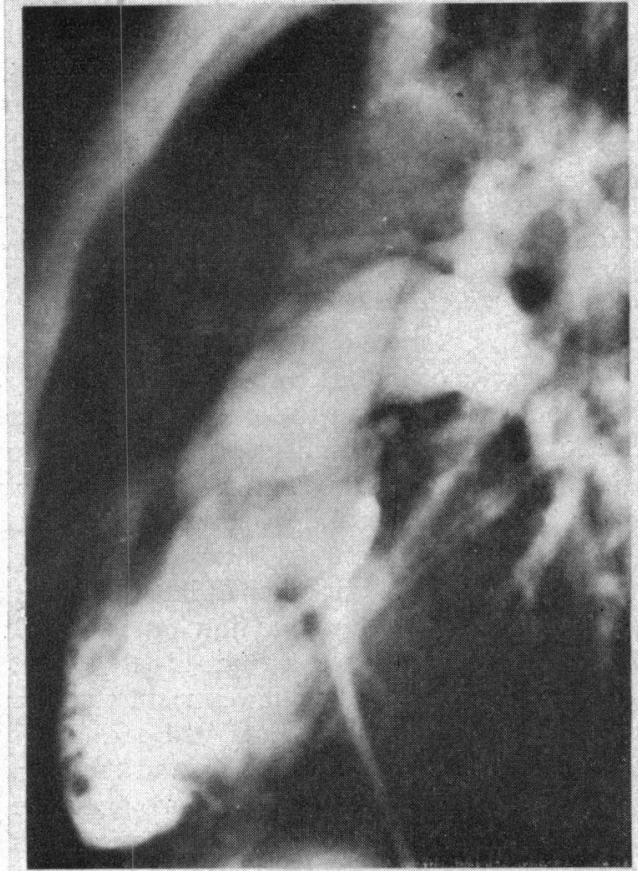

a

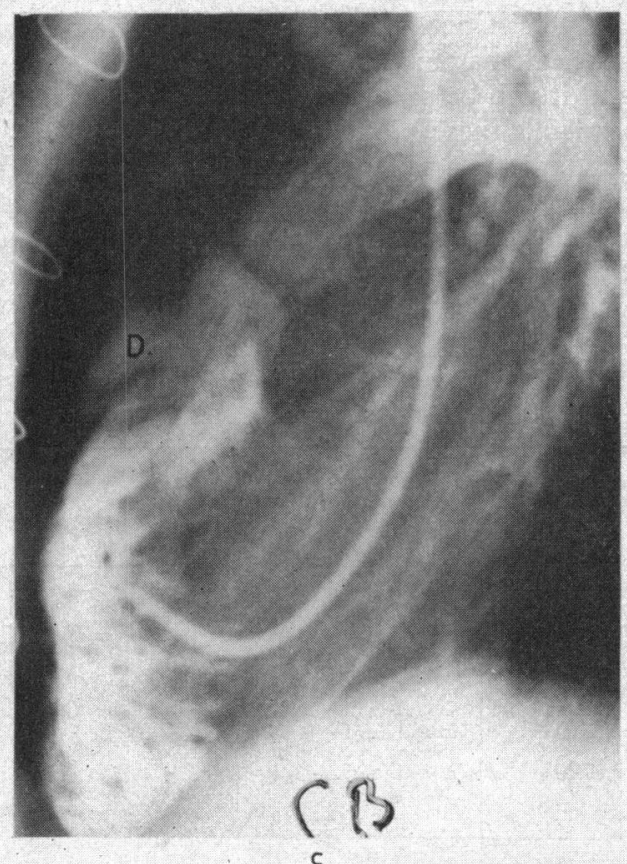

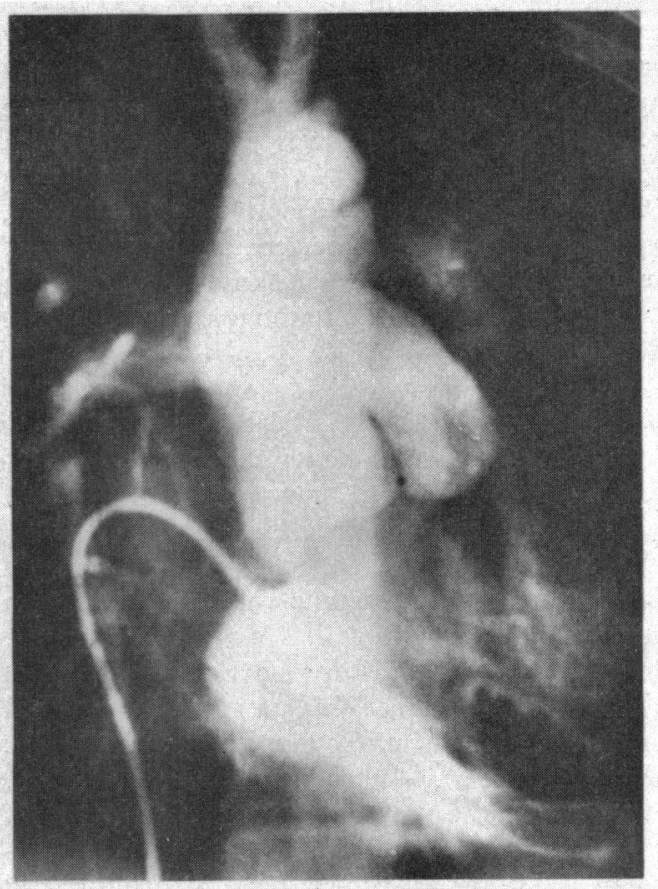

b

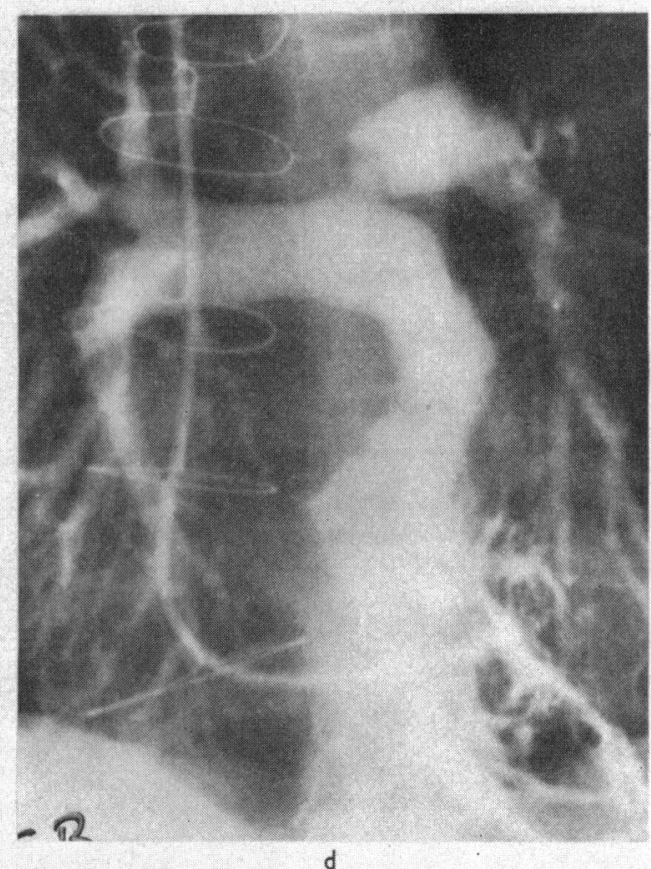

d

FIG. 8.-Right ventricular angiocardiogram of Case 16 before (upper) ( $a=$ lateral, $b=$ frontal) and after (lower) ( $c=$ lateral, $d=$ frontal) operation, showing early filling of aorta from right ventricle and severe pulmonary stenosis before, but wide outflow tract and no early aortic filling after operation. There is a small diverticulum (D) in the right ventricular outflow tract at the site of the ventriculotomy (both on left). (The pulmonary valve is closed.) 


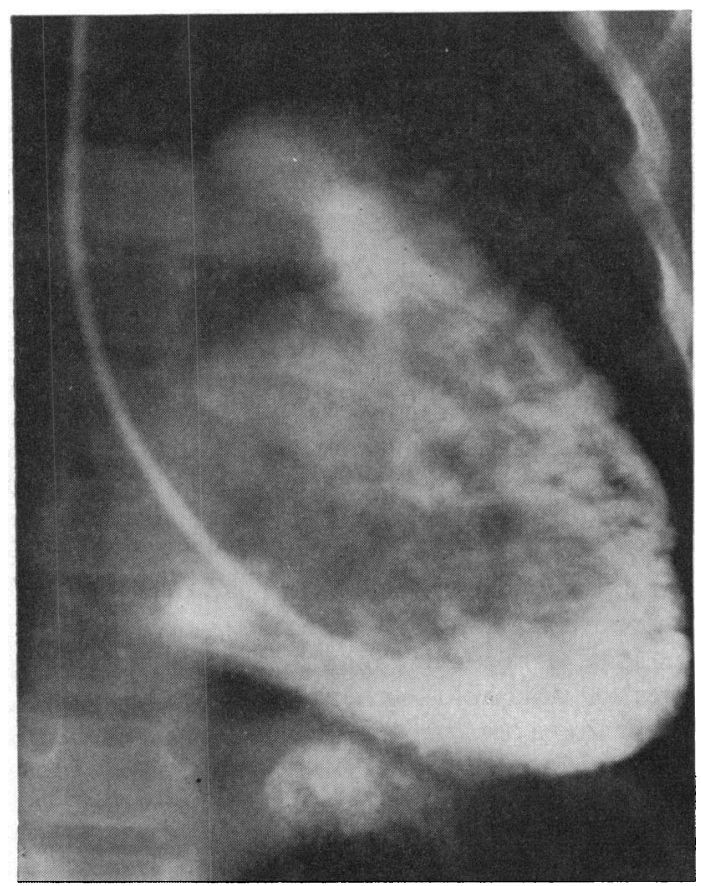

FIG. 9.-Right ventricular angiocardiogram (lateral projection) of Case 7, showing enormous dilatation of the right ventricle due to pulmonary incompetence.

abnormality, with gradients less than $20-25 \mathrm{~mm}$. $\mathrm{Hg}$, no pulmonary incompetence, and no shunts. The remaining 10 patients may be regarded as very satisfactory and unlikely to give rise to anxiety in the future. These results are in general agreement with those of Gotsman (1966) who studied 11 patients after radical correction and found pulmonary incompetence in 6 and residual obstruction in 2.

The angiographic appearances indicate that excellent anatomical results are achieved in the majority of patients (Gotsman, 1966). The appearances of residual obstruction and patency of the ventricular septum in the relevant patients were predictable from the hæmodynamics or physical signs, but the diverticulum-like lesions near the ventriculotomy cannot be diagnosed without angiography, and may be present in a number of patients after an operation of this type. Their significance is uncertain, but it seems improbable that they will cause trouble in the future.

The raised right ventricular end-diastolic pressures might be regarded as evidence of impaired function, but diastolic pressures alone do not give a reliable index of function. It is possible that some reduction in compliance follows the healing of the ventriculotomy scar, but the normal ventricular diastolic volumes in the few cases studied encourage

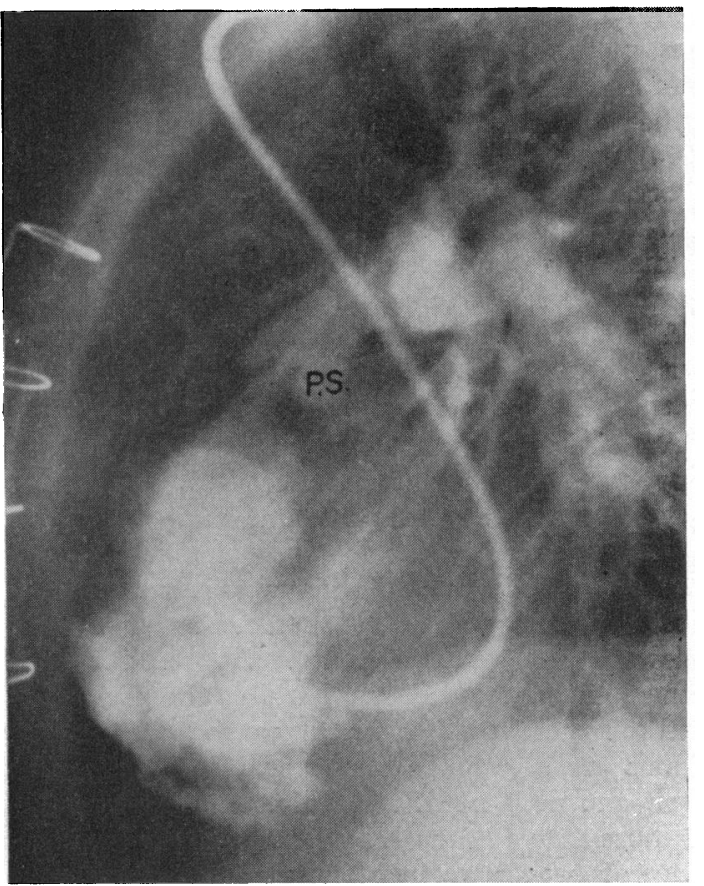

FIG. 10.-Right ventricular angiocardiogram of Case 9, showing residual pulmonary valve stenosis (PS) and outline of the aortic valve cusp from the right ventricle, after operation.

the belief that ventricular function is likely to be adequate and to remain so, though the thermodilution method still remains to be fully validated. However, end-diastolic pressures in the right ventricle were often raised before operation. Pulmonary incompetence does not seem to contribute to a raised end-diastolic pressure, which was increased in 9 of the 10 patients with unsatisfactory results (Table VII).

The presence of right bundle-branch block after operation has not so far appeared to contribute any disability. The development of left axis deviation is interesting and may be related to interference with arborization conduction bundles. Similar changes are often seen after closure of simple ventricular septal defects, in our experience.

From the clinical aspect these patients have all been greatly improved, and even those with shunts or severe pulmonary incompetence have striking improvement in symptoms. The results obtained by special investigations are helpful in assessing the significance of clinical signs after operation.

A systolic murmur of medium intensity and length, with audible pulmonary closure, denotes an excellent result with little or no residual obstruction. Even a loud murmur immediately after operation may be compatible with an excellent final result, 
for it may diminish gradually as the obstruction regresses. It is unusual for the murmur to become faint, as it does after resection of lone valvar stenosis without ventricular septal defect (Oakley et al., 1964), in view of the more extensive outflow tract disorders in most cases. The intensity of the murmur is increased by the presence of appreciable pulmonary incompetence because of the increased stroke volume of the right ventricle.

A soft or medium intensity early diastolic murmur denotes slight or moderate pulmonary incompetence which is unlikely to be of future significance.

A high jugular venous pressure up to 6 or $8 \mathrm{~mm}$. above the sternal angle is a frequent occurrence, and may be expected to fall to normal in 6-12 months. It is not specifically related to any one factor, but is probably mainly due to residual obstruction, and possibly to some reduction in ventricular compliance following the ventriculotomy. Appreciable pulmonary incompetence, or a left-to-right shunt, will tend to maintain a high venous pressure. A raised venous pressure in no way precludes an excellent result and need not cause anxiety unless it persists for more than 12 months, or is associated with evidence of congestive heart failure, notably hepatomegaly, or with signs of severe pulmonary incompetence or a persistent shunt.

The development of a systolic wave of tricuspid incompetence should arouse suspicion of damage to the tricuspid valve at the time of operation or by endocarditis.

A pansystolic murmur, active ventricular pulsation, and apical diastolic rumble all suggest that a left-to-right shunt is present at ventricular level.

The long-term prognosis of most of these patients seems to be excellent; that of the patients with severe pulmonary incompetence and persistent shunts is less certain. Decision regarding further operation is difficult, for all the patients have been considerably improved, and the risks of further operation must be weighed carefully against those of conservative treatment. It is probable that Cases 5, 9 , and 12 will need re-operation. Case 5 has had bacterial endocarditis since operation, with damage to the tricuspid valve, Case 9 still has a right-to-left shunt, and Case 12 is in heart failure controlled by diuretics.

We feel that the results in this small pilot series encourage the belief that ventricular structure and function are satisfactory in the majority of patients after radical correction, and that the great improvement in ail but a very small minority of those who survive the operation fully justifies a difficult operation to relieve a hazardous anomaly which seriously limits normal life both symptomatically and prognostically.
SUMMARY

The over-all results of radical correction of the tetralogy of Fallot in 133 patients are presented briefly. Although initial mortality was high, it subsequently fell to 19 per cent in 56 patients operated upon.

Of the 36 patients who died, 7 had persistence of the ventricular septal defect, and died in the early post-operative period. There were 2 late deaths.

Improvement in the survivors was dramatic, with relief of dyspnoea and cyanosis to a degree that fully justified the operation.

The detailed over-all results in the 133 patients will be published elsewhere. This paper presents the results of detailed clinical, hæmodynamic, and angiographic studies of ventricular function and structure in 24 patients who have been treated by radical correction of the tetralogy of Fallot. The patients were selected for special study, or because it was felt advisable to check on ventricular function from the aspect of long-term prognosis. The improvement in all patients was dramatic, with relief of cyanosis and dyspnœea. However, in order to test long-term prognosis, deliberately over-rigid criteria for a fully satisfactory result were set.

Of the 24 patients, 10 had appreciable systolic gradients (more than $50 \mathrm{~mm} . \mathrm{Hg}$ ) across the right ventricular outflow tract, a persistent shunt at ventricular level, or severe pulmonary incompetence, or a combination of these lesions. Ten patients had minor degrees of outflow tract obstruction and mild pulmonary incompetence, and were considered satisfactory. Four patients had well-nigh perfect restoration of normal function with minimal or absent outflow tract gradients, no pulmonary incompetence and no shunts.

A raised right ventricular end-diastolic pressure after operation was present in many and was often related to a raised jugular venous pressure. The jugular venous pressure was raised after operation in 15 patients, who were denied an excellent result, and fell to normal in 6-12 months. It did not appear to be related specifically to any one factor but was probably connected with the high right ventricular end-diastolic pressure, which in turn was possibly due to a reduction in compliance of the right ventricle following the ventriculotomy. Severe pulmonary incompetence or a left-to-right shunt exaggerated and perpetuated the raised jugular venous pressure.

Angiocardiography revealed unexpected dilatation lesions of the right ventricle in the region of the ventriculotomy in 4 patients; the significance of this is discussed.

The occurrence of right bundle-branch block in 23 of the 24 patients after operation is noted. 
It is concluded that the long-term prognosis in the majority of patients following radical correction of the tetralogy of Fallot is excellent despite the presence of the ventriculotomy scar and right bundle-branch block. The prognosis is less certain for the minority who are left with important residual lesions.

We are grateful to our surgical colleagues, $\mathrm{Mr}$. W. P. Cleland and Professor H. H. Bentall, for providing data and for their advice in the preparation of this paper, and to Mr. Gerald Rainbow and his technical staff for assistance with the investigations. We are indebted to Professor R. E. Steiner for help with the angiographic studies.

\section{REFERENCES}

Anderson, I. M., Newman, C. G. H., and Urquhart, W. (1965). Fallot's tetralogy-Some radiological and other findings in the first few years after total correction. Brit. $\mathcal{F}$. Radiol., 38, 81 .

Bahnson, H. T., Spencer, F. C., Landtman, B., Wolf, M. D., Neill, C. A., and Taussig, H. B. (1962). Surgical treatment and follow-up of 147 cases of tetralogy of Fallot treated by correction. $\mathcal{F}$. thorac. cardiovasc. Surg., 44, 419.

Barnard, C. N., and Schrire, V. (1961). The surgical treatment of the tetralogy of Fallot. Thorax, 16, 346.

Bristow, J. D., Menashe, V. D., Griswold, H. E., and Starr, A. (1961). Total correction of tetralogy of Fallot: Complications and results. Amer. F. Cardiol., 8, 358.
Goodwin, J. F., and Abdin, Z. H. (1959). The cardiogram of congenital and acquired right ventricular hypertrophy. Brit. Heart f., 21, 523.

Gotsman, M. S. (1966). Hæmodynamic and cine-angiocardiographic findings after one-stage repair of Fallot's tetralogy. Brit. Heart F., 28, 448.

Kirklin, J. W., Payne, W. S., Theye, R. A., and DuShane, J. W. (1960). Factors affecting survival after open operation for tetralogy of Fallot. Ann. Surg., 152, 485.

Malm, J. R., Bowman, F. O., Jr., Jameson, A. G., Ellis, K., Griffiths, S. P., and Blumenthal, S. (1963). An evaluation of total correction of tetralogy of Fallot. Circulation, 27, 805.

Oakley, C. M., Braimbridge, M. V., Bentall, H. H., and Cleland, W. P. (1964). Reversed interatrial shunt following complete relief of pulmonary valve stenosis. Brit. Heart F., 26, 662.

Rapaport, E., Wong, M., Ferguson, R. E., Bernstein, P., and Wiegand, B. D. (1965). Right ventricular volumes in patients with and without heart failure. Circulation, 31, 531.

Smith, D. R., Effat, H., Hamed, M. A., and Omeri, M. Al (1965). Radiological and surgical anatomy in tetralogy of Fallot and the effect on surgical program. Brit Heart f., 27, 604.

Wong, M., and Dulake, M. (1966). Thermodilution studies of ventricular function after correction of the tetralogy of Fallot. Brit. Heart. F., 28, 426.

\section{ADDENDUM}

Since this paper was completed we have noted a fistula between coronary artery and right ventricle after radical correction in one patient (not in this series). 